\title{
ALBERT SILBERT (1915-1996)
}

\section{CARlos Alberto Medeiros ${ }^{1}$}

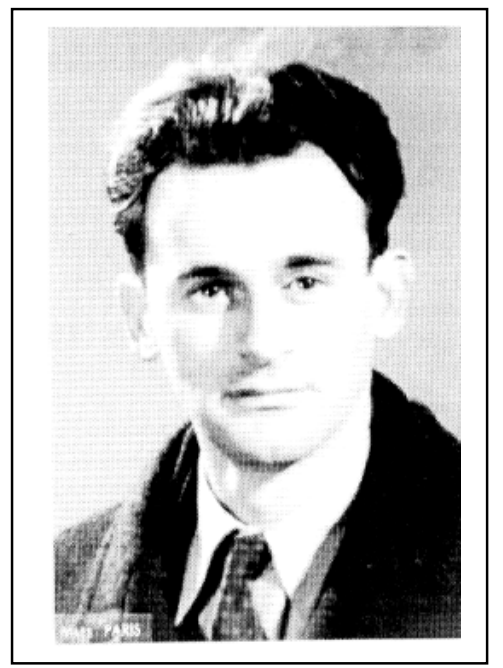

Falecido há pouco tempo, o historiador francês Albert Silbert deixou-nos uma contribuição inestimável para o estudo de questões relevantes da geografia humana portuguesa. $\mathrm{O}$ seu trabalho mais conhecido e utilizado é a densa e volumosa tese de "Doctorat d'État": Le Portugal Méditerranéen à la fin de l'Ancien Régime: XVIII. ${ }^{e}$ Début du XIX. ${ }^{e}$ Siècle. Contribution à l'histoire agraire comparée (2 edições, SEVPEN, Paris 1966; INIC, Lisboa 1978; mais de 1200 páginas, abundante indicação de fontes e de bibliografia). $\mathrm{O}$ espaço estudado corresponde fundamentalmente ao Alentejo e à área que o prolonga pela Beira Baixa, o que constitui uma unidade geográfica bem definida. Quanto ao marco cronológico escolhido, aparentemente breve, faz-nos descortinar as formas e estruturas ligadas ao aproveitamento rural dos solos, que por largo tempo marcaram a região, antes das importantes transformações ocorridas a partir de meados do século XIX. Mas as investigações de A. Silbert levam-no a recuar até séculos bem anteriores, alargando consideravelmente o período de tempo em relação ao qual esta obra pode ser consultada com proveito.

Não é este o lugar próprio para se traçar um resumo ou um comentário desta tese que, por tão variados méritos, se impõe. Aliás, o leitor poderá servir-se utilmente dum pequeno livro de Orlando Ribeiro, onde se condensa e analisa o que de mais importante ela contém (A evolução agrária no Portugal Mediterrâneo. Notícia e comentário de uma obra de Albert Silbert, CEG, Lisboa 1970). Gostaria apenas de chamar a atenção para dois aspectos, cujo interesse me parece pertinente realçar.

\footnotetext{
1 Professor Catedrático da Faculdade de Letras, Universidade de Lisboa. Investigador do Centro de Estudos Geográficos da Universidade de Lisboa. Centro de Estudos Geográficos, Faculdade de Letras, Cidade Universitária, 1699 Lisboa Codex. Fax: (351-1) 79386 90; E-mail: ceg@mail.telepac.pt
} 
O primeiro diz respeito à identificação e caracterização de numerosas formas de "colectivismo agrário" no Alentejo, o que constitui, segundo Orlando Ribeiro, no seu trabalho citado, "uma das revelações mais inesperadas da obra de SILBERT - pois os exemplos do Sul do País eram desconhecidos ou quase dos autores que até agora se haviam ocupado do assunto" (p. 155).

O segundo, de âmbito mais geral e significado bem profundo, relaciona-se com as íntimas relações entre História e Geografia tecidas ao longo das numerosas páginas do trabalho e, certamente, das minuciosas investigações que a elas conduziram. A. Silbert sentiu necessidade de conhecer com rigor o ambiente geográfico da área estudada; esse conhecimento, que juntou ao da documentação reunida em arquivos mais ou menos ricos, melhor ou pior organizados, constituiu uma das bases fundamentais das suas pesquisas e muito dele transparece através da elaboração final. Diversas páginas desta, tanto se enquadram no âmbito dum, como do outro domínio do conhecimento, e, no seu conjunto, o livro constitui brilhante ilustração da riqueza e dos fecundos resultados a que dão origem as orientações metodológicas que os associam. Disto mesmo dá conta a nota de Mariano Feio que adiante se publica.

Deve acrescentar-se que muitos outros trabalhos de A. Silbert se revelam de grande interesse para o geógrafo (consulte-se a notícia bibliográfica incluída em Ler História, $\mathrm{n}^{\circ}$ 32, Lisboa 1997, p. 176-177). A problemática das estruturas económicas e sociais portuguesas das primeiras décadas do século XIX, que tanto interesse tem para a compreensão dos rumos que guiaram a geografia humana do nosso país, está tratada com profundidade e rigor na colectânea de estudos intitulada Do Portugal de Antigo Regime ao Portugal Oitocentista (Lisboa 1972). No âmbito da mesma temática e com o mesmo claro rigor, insere-se o trabalho intitulado Le problème agraire portugais au temps des premières Cortès libérales (1821-1823) (Paris 1968). Um artigo de grande importância, que se encontra na colectânea citada, merece referência especial: "O colectivismo agrário em Portugal. História de um problema" (p. 211-297).

A breve notícia da obra de A. Silbert, que aqui se dá, constitui apenas, necessariamente, pálido reflexo da sua actividade. Mas era indispensável deixá-la consignada nas páginas desta revista, na altura em que desaparece do número dos vivos este historiador francês que tão sólidas relações estreitou com a geografia portuguesa. 